\title{
Keyhole Endoscopic Hematoma Evacuation in Patients
}

\section{Anahtar Deliği Endoskopik Hematom Boşaltma}

\author{
Hongwei $\mathrm{ZHU}^{1,2}$, Zhanxiang $\mathrm{WANG}^{2}$,Wei $\mathrm{SHI}^{1}$ \\ ${ }^{1}$ The Second Affiliated Hospital, Xi'an Jiaotong University, Department of Neurosurgery, Xi'an, China \\ ${ }^{2}$ The First Affiliated Hospital, Xiamen University, Department of Neurosurgery, Xiamen, China
}

Correspondence address: Wei SHI / E-mail: sweins@21cn.com

\begin{abstract}
AIM: Keyhole endoscopy is a promising therapeutic option for spontaneous intracerebral hemorrhage (ICH). We sought to compare the clinical outcomes between keyhole endoscopy surgery and craniotomy for basal ganglia $\mathrm{ICH}$.

MATERIAL and METHODS: The authors performed a retrospective analysis of the clinical and radiographic data obtained in 28 keyhole endoscopic procedures and 30 craniotomy procedures. Hematoma evacuation rate, infection rate, rebleeding and mean operation time were recorded as primary end points. Outcome Scale (GOS) values were recorded at the 3-month postoperative follow-up. The operation time from symptom onset is also studied between $<8$ hours group and $8-24$ hours group.

RESULTS: The evacuation rate was significantly higher in the endoscopy group compared with the craniotomy group $(P<0.05)$, and infectious rate was lower in the endoscopy group compared with the craniotomy group $(P<0.05)$. Mortality rates between the 2 groups did not show statistically significant differences. The patients operated within $8 \mathrm{~h}$ had better outcome (GOS 4 and 5 ) than that operated between $8-24 \mathrm{~h}$ ( $p$ $<0.05)$.
\end{abstract}

CONCLUSION: The data indicate that in patients with $\mathrm{ICH}$, keyhole endoscopic surgery is safe and feasible, while operation within $8 \mathrm{~h}$ can promote recovery of patients. These preliminary results warrant further study in a large, prospective, randomized trial in the near future.

KEYWORDS: Keyhole endoscopy, Intracerebral hemorrhage, Operation timing, Minimally invasive surgery

\section{öz}

AMAÇ: Anahtar deliği endoskopisi spontan intraserebral kanama (ISK) için ümit verici bir terapötik seçenektir. Bazal gangliada iSK için anahtar deliği endoskopi cerrahisi ve kraniyotomi arasında klinik sonuçları karşılaştırmak istedik.

YÖNTEM ve GEREÇLER: Yazarlar 28 anahtar deliği endoskopik işlem ve 30 kraniyotomi işleminde elde edilen klinik ve radyografik verilerin retrospektif bir analizini yapmışlardır. Hematom boşaltma oranı, enfeksiyon oranı, tekrar kanama ve ortalama ameliyat süresi primer son noktalar olarak kaydedildi. Sonuç Ölçeği (GOS) değerleri 3 aylık postoperatif takipte kaydedilmiştir. Semptom başlangıcından operasyon süresi de $<8$ grup ve 8 -24 saatlik grup olarak çalışıımıştır.

BULGULAR: Boşaltma oranı endoskopi grubunda kraniyotomi grubuna göre anlamlı ölçüde daha yüksektir $(P<0,05)$ ve enfeksiyon oranı endoskopi grubunda kraniyotomi grubundan daha düşüktür $(P<0,05)$. 2 grup arasındaki mortalite oranı istatistiksel olarak anlamlı farklılıklar göstermemiştir. 8 saat içinde ameliyat edilen hastaların sonuçları (GOS 4 ve 5) 8-24 saat arasında ameliyat edilenlerden daha iyidir ( $p<0,05$ ).

SONUÇ: Veriler ISK hastalarında anahtar deliği endoskopik cerrahinin güvenli ve kabul edilebilir olduğunu ve 8 saat içinde yapılan ameliyatın hastaların iyileşmesini desteklediğini göstermiştir. Bu ön sonuçların yakın gelecekte geniş, prospektif, randomize bir çalışmada daha ileri değerlendirilmesi gerekir.

ANAHTAR SÖZCÜKLER: Anahtar deliği endoskopisi, İntraserebral kanama, Operasyon zamanlaması, Minimal invaziv cerrahi

\section{INTRODUCTION}

Surgical management of $\mathrm{ICH}$ is still a matter of controversy with regard to indications, timing, and method. Minimally invasive hematoma evacuation using a neuroendoscope and the rapid development of neuroendoscope technology for the surgical treatment of ICH provides a useful option $(4,16,20)$. According to the AHA/ASA guidelines for the management of spontaneous intracerebral hemorrhage (3), the effectiveness of minimally invasive ICH evacuation utilizing the endoscopic method is still uncertain and needs to be further tested in clinical trials. Supporting evidence from controlled trials is lacking. Therefore, we present our series of cases involving patients with basal ganglia $\mathrm{ICH}$ who underwent keyhole endoscopic and traditional craniectomy hematoma evacuation and discuss the safety and effectiveness of neuroendoscopic surgery, The operation time from symptom onset is also studied.

\section{MATERIAL and METHODS}

To qualify for inclusion in this study, patients had to have the following features: 1) Aged 35-70 years; 2) CT-confirmed basal ganglia hemorrhage; 3) Hematoma volume >30ml; 
4) Surgery to be instituted within 24 hours of the onset of clinical symptoms. Cases of deep coma with Glasgow Coma Scale (GCS) score of 3 and 4 were excluded. We also excluded patients with posttraumatic intracerebral hematomas, tumor bleeding, aneurysmal or arteriovenous hemorrhage, and bleeding tendencies caused by uremia, liver cirrhosis, or anticoagulation therapy.

The study group (keyhole endoscopy group) consisted of 28 consecutive adult patients between July 2008 and November 2010. The keyhole endoscopy group was matched to a historical control group (traditional craniotomy group), a series of 30 consecutive patients treated by craniotomy at our department between January 2007 and November 2010. Clinical characteristics of the patients for hematoma volume and age showed a significant difference between the groups $(p<0.05)$, as detailed in Table I.

\section{Traditional craniotomy}

Under general anesthesia, our surgical team drew a question mark on the temporal scalp of each patient. After opening the dura, we entered the hematoma cavity via a transcortical corridor through the inferior temporal gyrus or middle temporal gyrus approach. After removing the hematoma, the dura was closed and the bone flap was put back to its position.

\section{Keyhole endoscopic surgery}

For all basal ganglia hemorrhage, we used the transtemporal approach, A 5-cm vertical incision was made over the temporalis muscle and extended superiorly slightly. The temporalis muscle was split and a burr hole was made. The bone flap was made into a craniectomy about $2.5 \mathrm{~cm}$ in diameter. A cruciate dural opening was made. The authors confirmed the location of the hematoma using a stylet. A cortical incision was then made over a relatively silent area of the cortex and as near to the hematoma as possible. The transparent plastic sheath $(10 \mathrm{~mm}$ in inside diameter) was inserted along with the stylet. The 4-mm endoscope was introduced into the transparent sheath to provide visualization during hematoma removal. Depending on the surgeon's preference, the surgeon may hold the suction in his right hand and the endoscope in his left hand, and the assistant may hold the sheath. The hematoma was then evacuated using mild suction. High-pressure suction was usually avoided as it may cause further damage to the walls of the hematoma cavity. Clots that are adherent to the walls of the cavity especially anteriorly and medially are left alone, as evacuation of these may stir up further bleeding or may cause extensive damage to the internal capsule and thalamus. The ventricle can be opened if hemorrhage is associated with rupture into ventricle. When a bleeding vessel was encountered, the surgical field was kept clear with continuous irrigation and suction. Hemostasis was achieved by continuous saline irrigation and pressure packing. The identified bleeding artery was electrically coagulated with a suction cannula. When all procedures were completed, an external ventricular drain was left in the ventricle for several days if the ventricle was opened.

\section{Assessments and End Points}

Outcome variables included hematoma evacuation rate, infection rate, rebleeding rate, and mean operation time. The outcome was also measured three months later. The 3-month Glasgow Outcome Scale (GOS) was the major end point. Hematoma volume was estimated by the following equation: $\mathrm{V}=$ length $\times$ width $\times$ thickness $/ 2$ (11). The hematoma evacuation rate (\%) was defined as (preoperative volumepostoperative volume)/(preoperative volume) $\times 100 \%$. Rebleeding was identified when the postoperative CT volume was either greater than the preoperative volume or there was a $5 \mathrm{ml}$ difference in the pre- and postoperative $\mathrm{CT}$ blood volume measurements. We also discuss the operation timing from symptom onset. The categories for the timing of surgery were as follows: Ultra-early ( $<8$ hours), and early (8-24 hours). We compared mortality, good outcome and postoperative rebleeding between the 2 groups after 3 months.

\section{Statistic analysis}

Statistical analysis was carried out using T-analysis and Fisher's exact or $X^{2}$ test. A P value $<0.05$ was considered statistically significant.

\section{Illustrative case}

A 60-year-old woman was admitted to our hospital because of an altered level of consciousness and right hemiparesis. On initial consultation, his level of consciousness was E1V2M4 on the GCS. Head CT revealed left ICH in the basal ganglia with

Table I: The Clinical Features Between the Keyhole Endoscopy Group and the Control Group of Traditional Craniotomy

\begin{tabular}{|c|c|c|c|}
\hline & Endoscopy group & Craniotomy group & $\mathbf{P}$ \\
\hline Number of cases & 28 & 30 & / \\
\hline Male:Female & $17: 11$ & $15: 15$ & 0.441 \\
\hline Age (Years) & $60.6 \pm 7.2^{*}$ & $64.6 \pm 5.0$ & 0.017 \\
\hline History of hypertension & $21(75 \%)$ & $21(70 \%)$ & 0.670 \\
\hline Hematoma volume (ml) & $53.7 \pm 15.8^{*}$ & $63.9 \pm 17.0$ & 0.021 \\
\hline GCS & $8 \pm 2$ & $7 \pm 2$ & 0.136 \\
\hline IVH, n (\%) & $14(50.0 \%)$ & $22(73.3 \%)$ & 0.067 \\
\hline
\end{tabular}

${ }^{*} P<0.05$ 
an estimated volume of $60 \mathrm{ml}$. The patient was intubated and underwent endoscopic surgery as previously described to evacuate the hematoma. Postoperative CT scanning revealed almost complete removal of the thalamic hematoma (Figure 1). A drain was kept in place for 2 days after the operation. No intraventricular injection of an anticoagulant, such as urokinase, was needed for this patient. She regained consciousness 4 day later and displayed a right-sided hemiparesis and motor aphasia.

\section{RESULT}

Twenty-eight cases of endoscopic surgery (keyhole endoscopy group) and 30 historical controls (craniotomy group) were evaluated. All patients had altered level of consciousness with or without focal neurologic deficit. Baseline characteristics are summarized in Table I. More than half of the group was male, and the mean patient age was 62.6 years. The median time from ictus to surgery was 8 hours in the endoscopy group and 6 hours in the craniotomy group. The hematoma volume was $31-88 \mathrm{ml}$ (median, $60.6 \mathrm{ml}$ ) in the endoscopy group and $40-115 \mathrm{ml}$ (median, $64.6 \mathrm{ml}$ ) in the craniotomy group. The between-group difference in hematoma volume and age were statistically significant $(P<0.05)$.

The evacuation rate in the endoscopy group was from $88 \%$ to $100 \%$, while the evacuation rate of the craniotomy group was from $50 \%$ to $100 \%$.The evacuation rate was significantly higher in the endoscopy group than in the craniotomy group
(92.1\% vs $86.5 \% ; P<0.01)$. There was 1 rebleeding case in the endoscopy group and 3 cases in the craniotomy group, and there was no significant difference between the two groups $(P>0.05)$. Infectious complication involved pneumonia and wound infection. There were 12 cases of pneumonia and 3 cases of wound infection in the craniotomy group; and 5 cases of pneumonia and 1 case of wound infection in the endoscopy group with a significant difference between the two groups ( $21.4 \%$ vs. $50.0 \%, P<0.05)$. Median operative time was longer in the craniotomy group than the endoscopic group (232 $\mathrm{min}$ vs. $138 \mathrm{~min}, P<0.001$, Table II).

There were 7 cases of death among the 58 patients. Two patients in the endoscopy group died from respiratory failure due to pneumonia. Three deaths in the craniotomy group were due to pneumonia, and 2 deaths resulted from rebleeding. Mortality rates were $7.1 \%$ for the endoscopy group, and $16.7 \%$ for the craniotomy group, but mortality rates between the 2 groups did not show a statistically significant difference $(P>0.05)$. There was no difference in the GOS score between the 2 groups 3 months later ( $P>0.05$, Table III and Figure 2), although the endoscopy group had a better outcome trend (GOS4 and GOS5) than the craniotomy group.

Traditional craniotomy group timing from surgery to onset was 3-20 hours. In the minimally invasive surgical operation group, the shortest duration was 4 hours and the longest 18 hours from the onset, with an average of 8 hours. There
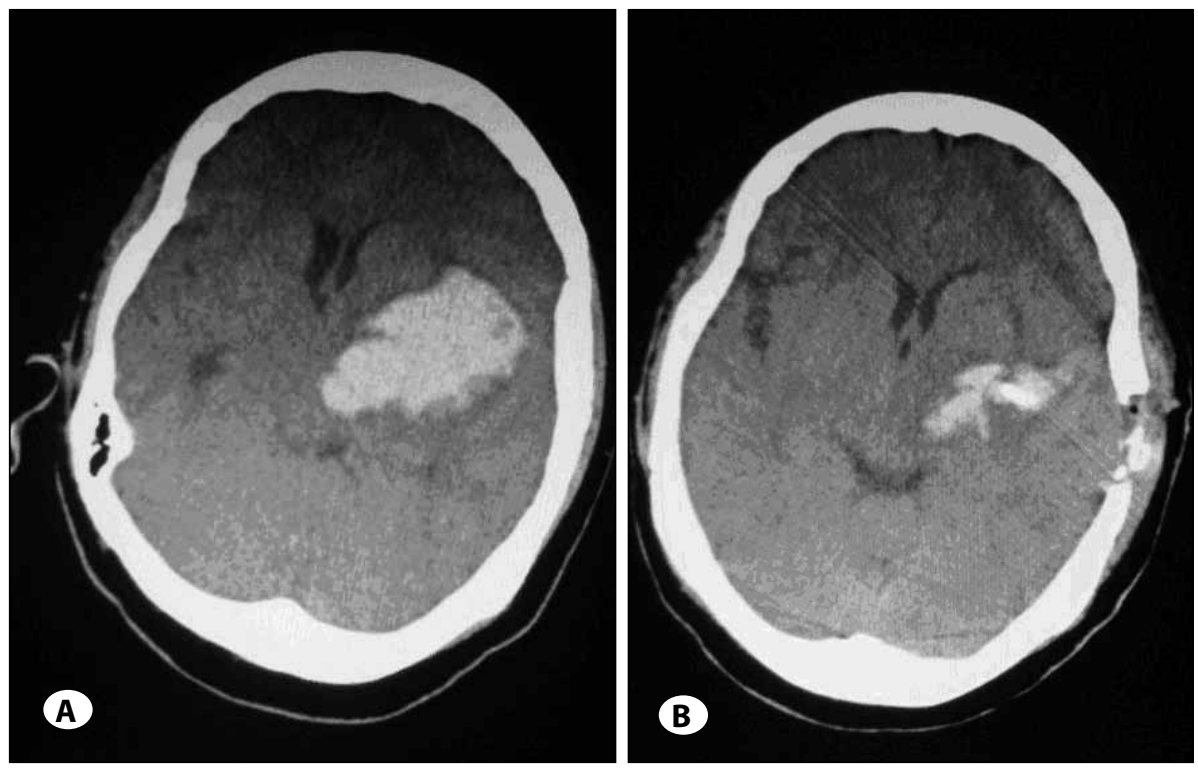

Figure 1: A) Axial CT scan showing a large left sided basal ganglia hemorrhage with an estimated volume of $60 \mathrm{ml}$.

B) Postoperative CT scan demonstrating only a little left of the hematoma.

Table II: Surgical Results

\begin{tabular}{|c|c|c|c|}
\hline & Endoscopy group & Craniotomy group & $\mathbf{P}$ \\
\hline Median evacuation rate (\%) & $92.1 \pm 3.9^{*}$ & $86.5 \pm 9.1$ & 0.004 \\
\hline Rebleeding, n (\%) & $1(3.6 \%)$ & $3(10.0 \%)$ & 0.612 \\
\hline Infection, n (\%) & $6(21.4 \%)^{*}$ & $15(50.0 \%)$ & 0.024 \\
\hline Median operative time (min) & $138 \pm 15^{*}$ & $232 \pm 16$ & $<0.001$ \\
\hline
\end{tabular}


Table III: Clinical Outcomes

\begin{tabular}{|l|c|c|c|} 
& Endoscopy group & Craniotomy group & P \\
\hline GOS 1, n (\%) & $2(7.1 \%)$ & $5(16.7 \%)$ & 0.425 \\
\hline GOS 2, n (\%) & $2(7.1 \%)$ & $3(10.0 \%)$ & 1.0 \\
\hline GOS 3, n (\%) & $17(60.7 \%)$ & $19(63.3 \%)$ & 1.0 \\
\hline GOS 4, n (\%) & $5(17.9 \%)$ & $3(10.0 \%)$ & 0.464 \\
\hline GOS 5, n (\%) & $2(7.1 \%)$ & 0 & 0.229
\end{tabular}

$P>0.05$

Table IV: The Surgical Result and Complications Between the $<8 \mathrm{~h}$ group and 8-24h Group

\begin{tabular}{|c|c|c|c|}
\hline & $<8 h$ & $8-24 h$ & $\mathbf{P}$ \\
\hline Mortality, n (\%) & $5(14.7 \%)$ & $2(8.3 \%)$ & 0.688 \\
\hline Good outcome, n (\%) & $9(26.5 \%)^{*}$ & $1(4.2 \%)$ & 0.035 \\
\hline Rebleeding, n (\%) & $2(5.9 \%)$ & $2(8.3 \%)$ & 0.719 \\
\hline
\end{tabular}

${ }^{*} P<0.05$

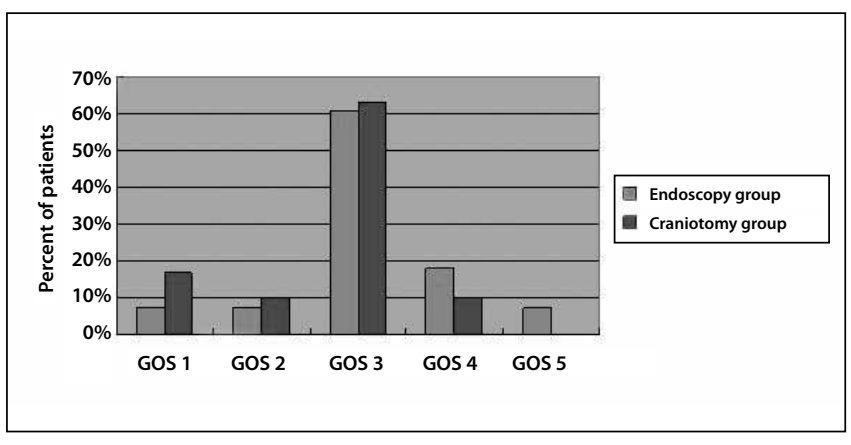

Figure 2: Clinical outcomes.

were 34 cases operated within 8 hours and 24 cases operated within 8-24 hours. The ultra-early group had better outcomes (GOS 4 and 5 ) than the early group ( $26.5 \%$ vs. $4.2 \% ; P<0.05$, Table IV and Figure 3).

\section{DISCUSSION}

\section{ICH in China mainland}

There are no comprehensive statistics about the incidence of stroke in China mainland currently. The data of 2000, from Beijing, Shanghai, Changsha, three major cities of the information, reveal that the incidence of stroke is from 76.1 to $150.0 / 10$ million, and $\mathrm{ICH}$ accounted for $18.9-47.6 \%$ of all stroke cases (8). Another study including more information from more cities showed that ICH accounted for $17.1-39.4 \%$ in subtypes of stroke (21). In Western populations, ICH accounted for a rate of $6.5 \%$ to $19.6 \%$ and the annual incidence rate is $20.9-28.0 / 10$ million. The average mortality rate after 1 month of $\mathrm{ICH}$ is $40.4 \%$, of which Japan has $16.7 \%$, the lowest in the world, and China 49.4\%, higher than the world average $(1,21)$. Chinese populations are rapidly adopting Western dietary habits, including increased energy intake, fat intake, and alcohol consumption, and decreased physical activity and cigarette smoking in recent years, together with China's economic development. Ischemic stroke was more

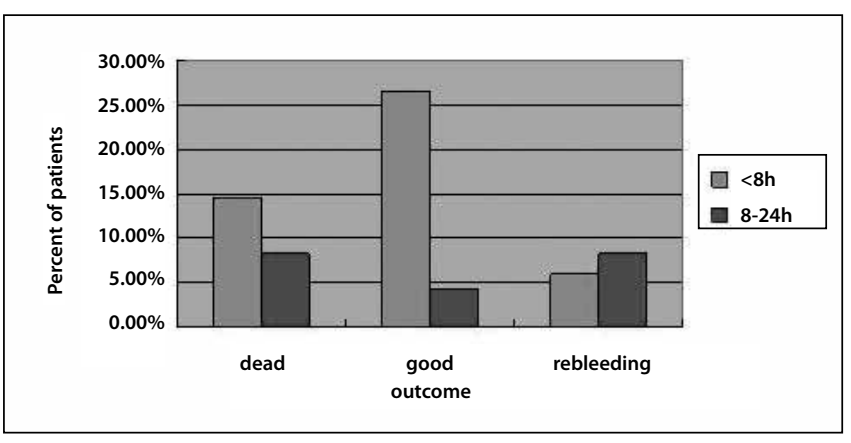

Figure 3: Surgical result and rebleeding.

frequent and the proportion was higher than hemorrhagic stroke in Chinese populations, which is close to the subtype composition in the Western society (9). It should be noted that with today's China becoming an aging society, the number of high-risk people older than 55 years wil gradually increase and the annual ICH incidence may be on the rise (1).

\section{Surgical treatment in $\mathrm{ICH}$}

The role of surgery in treating $\mathrm{ICH}$ is not fully established. Results from the STICH trial have greatly influenced the clinical management of $\mathrm{ICH}(10,13)$. However, there were some limitations to STICH trial, which as a worldwide multicenter trial involved diverse patient inclusion and surgical procedures. Surgical treatment is recommended when supratentorial $\mathrm{ICH}$ volume is at least $30 \mathrm{ml}$ for life-saving purposes, which has been recognized by many surgeons (6). The purpose of surgery is to reduce the mass effect of hematoma, and thus decrease ICP, and restrict the cerebral edema by the blood components. Traditional craniotomy degrades the operative effect because of its long operation time, big wound and more postoperative complications. It is plausible that early and complete removal of ICH via a minimally invasive method can reduce the secondary injury associated with $\mathrm{ICH}(5)$. 


\section{Endoscopic surgery}

Evacuation of ICH by the endoscope was first reported by Auer in 1985 (2). The last decade has brought significant advances in endoscopic surgical instruments and techniques that have improved patient outcomes $(12,16,20)$. Recent reports on the rate of hematoma evacuation through endoscopic surgery have reached rates of $99 \%(15,17)$, and comparative studies about minimally invasive surgery and craniotomy are still rare. We believe that as long as the positioning is accurate, keyhole endoscopic surgery can achieve the effect of large craniotomy surgery. Direct identification of the bleeding point and coagulation of responsible vessels under endoscopic visual control facilitate hematoma evacuation, without overstretching the brain tissue. The hematoma evacuation rate in the endoscopic keyhole hematoma group was significantly higher than the traditional craniotomy group $(P<0.05)$, and the incidence of infection in the keyhole surgery group was significantly lower than the craniotomy group $(P<0.05)$, because of the mild brain injury, shorter operation time and quicker recovery. When we began to use endoscopic techniques in the treatment in $\mathrm{ICH}$, we prefered to choose open craniotomy when the hematoma volume was large. However, we did not have much experience and worried about the lower evacuation rate with endoscopy in large hematomas. We later found that endoscopic hematoma removal could provide a good evacuation rate even if the hematoma volume was bigger. This may be the reason hematoma volume was larger in the craniotomy group than that in endoscopy group $(p<0.05)$.

\section{Clinical Outcomes}

Differences in patient selection, surgical indication, operation timing, technique, and perioperative care made direct comparison difficult. The published research results by Nagasaka with a combination irrigation-coagulation suction cannula or multifunctional suction cannula showed the rate of good outcome (good recovery and moderate disability) at discharge as $17.3 \%(4 / 23)$, and $0(0 / 20)$ for the craniotomy group (17). Recently Kuo reviewed 68 cases of endoscopic treatment in cerebral hemorrhage with a mortality rate of $5.9 \%$, and surgery-related morbidity of $4.4 \%$ (12). In our group, systemic complications, and especially pulmonary infection in addition to the brain-related factors were an important cause leading to death. Four cases died because of respiratory failure following pneumonia among the 8 deaths. The incidence of infection was significantly lower in the keyhole endoscopic group than the craniotomy group, so if we control post-operative complications the lower incidence of lung infection can improve the prognosis of patients. Some authors believe that later (6-month) survival was correlated with age (7). We chose patients aged from 30 to 70 years old as they would have relative good tolerance for the operation and we could compare the clinical result. The age in the craniotomy group was older than that in the endoscopy group $(P<0.05)$, and it did not reach a significant difference in clinical outcome between the 2 groups. A larger, more balanced study would be needed to further confirm the clinical result of endoscopy.

\section{When to operate and Rebleeding}

It has been demonstrated that serum proteins originating from the intracerebral hematoma can result in early and prolonged (8 hours) edema after experimental $\mathrm{ICH}$ in a pig model (18). Clot removal at 3 hours has been proven to markedly reduce mass effect and edema at 24 hours in the same pig model of $\mathrm{ICH}$ (19). If very early surgery can remove most of the hemorrhage with minimal additional brain tissue damage, physicians may be able to reduce edema development and mass effect, prevent white matter damage, and improve clinical outcome in some patients. The problem linked with ultra-early surgery is rebleeding. A trial of 11 patients randomized within 4 hours of hemorrhage onset found that rebleeding occurred in $40 \%$ of the patients treated within 4 hours compared with $12 \%$ of the patients treated within 12 hours using the craniotomy method (14). There was a relationship between rebleeding and mortality in the 4-hour surgery group. According to Guidelines for the management of spontaneous intracerebral hemorrhage in adults, 2007 update, the preponderance of evidence supports operative removal within 12 hours, particularly through lessinvasive methods (3). Our study showed that operation within $8 \mathrm{~h}$ could lead to improved outcomes. In a nonrandomized report of putamenal clot evacuation in 100 patients within 7 hours of symptom onset, Kaneko point out the critical need to identify the bleeding lenticulostriate branch and coagulate it to prevent rebleeding postoperatively (9). We think that the bleeding point is better left untouched in cases that have achieved hemostasis. Meanwhile, continuous oozing from ruptured vessels should be exposed and be coagulated. This group of patients did not show that ultra-early surgery group compared with group operation in $8-24 \mathrm{~h}$ was much more likely to rebleed. We believe that intraoperative blood pressure rising to normal levels after coagulation to test whether the effect is exactly, and postoperative control of blood pressure in a relatively stable state is an important measure to prevent further bleeding.

\section{STUDY LIMITATION}

Our study has several potential limitations. This was a retrospective nonrandomized study involving a relatively small group. The patients in this study were highly selected patients with a GCS score of 3 and 4, and coagulopathy was excluded. These patients usually have a poor prognosis compared with the patients included in this study, and there was a significant difference in hematoma volume and age in our group. Therefore, the good surgical outcomes and functional results may be due to patient selection.

\section{CONCLUSION}

Keyhole endoscopic surgery significantly improved the hematoma evacuation rate in our cohort. Our findings indicate that keyhole endoscopic surgery is safe and feasible. We support the idea that keyhole endoscopic surgery can 
play a crucial role in the treatment of spontaneous ICH and that operation within $8 \mathrm{~h}$ could lead to improved outcomes in selected patients. However, these preliminary results warrant further study in a large, prospective, randomized trial in the near future.

\section{REFERENCES}

1. Van Asch CJ, Luitse MJ, Rinkel GJ, Tweel IV, Algra A, Klijn $\mathrm{CJ}$ : Incidence, case fatality, and functional outcome of intracerebral haemorrhage over time, according to age, sex, and ethnic origin: A systematic review and meta-analysis. The Lancet Neurology 9: 167 -176, 2010

2. Auer LM: Endoscopic evacuation of intracerebral haemorrhage. High-tech surgical treatment: A new approach to the problem? Acta Neurochir (Wien) 74:124-128, 1985

3. Broderick J, Connolly S, Feldmann E, Hanley D, Kase C, Krieger D, Mayberg M, Morgenstern L, Ogilvy CS, Vespa P, Zuccarello M: Guidelines for the management of spontaneous intracerebral hemorrhage in adults: 2007 update: A guideline from the American Heart Association/American Stroke Association Stroke Council, High Blood Pressure Research Council, and the Quality of Care and Outcomes in Research Interdisciplinary Working Group [J]. Circulation 116: 391-413, 2007

4. Chen CC, Lin HL, Cho DY: Endoscopic surgery for thalamic hemorrhage: A technical note. Surg Neurol 68:438-442, 2007

5. Cho DY, Chen CC, Chang CS, Lee WY, Ma MT: Endoscopic surgery for spontaneous basal ganglia hemorrhage: Comparing endoscopic surgery, stereotactic aspiration, and craniotomy in noncomatose patients. Surg Neurol 65: 547-556, 2006

6. Cho DY, Chen CC, Lee HC, Lee WY, Lin HL: Glasgow Coma Scale and hematoma volume as criteria for treatment of putaminal and thalamic intracerebral hemorrhage. Surgical Neurology 70: 628-633, 2008

7. Daverat P, Castel JP, Dartigues JF, Orgogozo JM: Death and functional outcome after spontaneous intracerebral hemorrhage. A prospective study of 166 cases using multivariate analysis. Stroke 22: 1-6, 1991

8. Jiang B, Wang WZ, Chen HL, Hong Z, Yang QD, Wu SP, Du XL, Bao QJ: Incidence and trends of stroke and its subtypes in China results from three large cities. Stroke 37(1):63-68, 2006

9. Kaneko M, Tanaka K, Shimada T, Sato K, Uemura K: Longterm evaluation of ultra-early operation for hypertensive intracerebral hemorrhage in 100 cases. J Neurosurg 58: 838-842, 1983

10. Kirkman MA, Mahattanakul W, Gregson BA, Mendelow AD: The effect of the results of the STICH trial on the management of spontaneous supratentorial intracerebral haemorrhage in Newcastle. Br J Neurosurg 22:739-746, 2008
11. Kothari RU, Brott T, Broderick JP, Barsan WG, Sauerbeck LR, Zuccarello M, Khoury J: The ABCs of measuring intracerebral hemorrhage volumes. Stroke 27:1304-1305, 1996

12. Kuo LT, Chen CM, Li CH, Tsai JC, Chiu HC, Liu LC, Tu YK, Huang AP: Early endoscope-assisted hematoma evacuation in patients with supratentorial intracerebral hemorrhage: Case selection, surgical technique, and long-term results. Neurosurg Focus 30(4):E9, 2011

13. Mendelow AD, Gregson BA, Fernandes HM, Murray GD, Teasdale GM, Hope DT, Karimi A, Shaw MD, Barer DH: Early surgery versus initial conservative treatment in patients with spontaneous supratentorial intracerebral haematomas in the International Surgical Trial in Intracerebral Haemorrhage (STICH): A randomised trial. Lancet 365:387-397, 2005

14. Morgenstern LB, Demchuk AM, Kim DH, Frankowski RF, Grotta JC: Rebleeding leads to poor outcome in ultra-early craniotomy for intracerebral hemorrhage. Neurology 56: $1294-1299,2001$

15. Nagasaka T, Inao S, Ikeda H, Tsugeno M, Okamoto T: Inflationdeflation method for endoscopic evacuation of intracerebral haematoma. Acta Neurochir (Wien) 150:685-690, 2008

16. Nagasaka T, Tsugeno M, Ikeda H, Okamoto T, Takagawa $Y$, Inao S, Wakabayashi T: Balanced irrigationsuction technique with a multifunctional suction cannula and its application for intraoperative hemorrhage in endoscopic evacuation of intracerebral hematomas: Technical note. Neurosurgery 65: 826-827, 2009

17. Nagasaka T, Tsugeno M, Ikeda H, Okamoto T, Inao S, Wakabayashi T: Early recovery and better evacuation rate in neuroendoscopic surgery for spontaneous intracerebral hemorrhage using a multifunctional cannula: Preliminary study in comparison with craniotomy. Journal of Stroke and Cerebrovascular Diseases 20: 208-213, 2009

18. Wagner KR, Xi G, Hua Y, Kleinholz, M, Courten-Myers GM, Myers RE, Broderick JP, Brott TG: Lobar intracerebral hemorrhage model in pigs: Rapid edema development in perihematomal white matter. Stroke 27:490-497, 1996

19. Wagner KR, Xi G, Hua Y, Zuccarello M, Courten-Myers GM, Broderick JP, Brott TG: Ultra-early clot aspiration after lysis with tissue plasminogen activator in a porcine model of intracerebral hemorrhage: Edema reduction and blood-brain barrier protection. J Neurosurg 90(3):491-498, 1999

20. YamamotoT,NakaoY,Mori K, Maeda M:Endoscopichematoma evacuation for hypertensive cerebellar hemorrhage. Minim Invasive Neurosurg 49:173-178, 2006

21. Zhang LF, Yang Jun, Hong Z, Yuan GG, Zhou BF, Zhao LC, Huang YN, Chen J, Wu YF: Proportion of different subtypes of stroke in China. Stroke 34:2091-2096, 2003 